\title{
THE DEFENSE INDUSTRY FAILED TO UNDERPIN THE NATIONAL ECONOMY
}

\section{V.Zatsepin}

The defense industry's 2015 preliminary performance results have been published. Early fulfillment of the state armament program's intermediate target index shows that military expenditures are of an excessive nature. Agencies' reporting data are controversial and need be specified. Russia's leaders declared about the need of diversification and conversion of the defense industry.

The Report of the Government of the Russian Federation on operating results submitted to the State Duma on 19 April $2016^{1}$ and the published data of the Ministry of Industry and Trade ${ }^{2}$ permit to assess the outputs of the Russian defense industry in the past year.

In 2015, growth in the output of the military-industrial complex (MIC) amounted to $12.9 \%$ which is 2.6 p.p. less than a year before ${ }^{3}$. With taking into account the dynamics of the past few years, from 2011 the MIC's output generally increased by $57.5 \%$, which is 22.5 p.p. short of the earlier declared target index $x^{4}$.

In 2015 , the volume of military products rose by $19.7 \%$. Thanks to the above, the share of modern samples of armament and military equipment in the armed forces of the Russian Federation rose to $47.2 \%$, having exceeded 1.5 times over the target index of the armament program (30\% by the end of 2015$)^{5}$.

Output growth was registered by the Ministry of Industry and Trade in all the sectors of the MIC, except for the conventional armament industry: the aircraft industry (5.9\%), the aerospace industry $(7.6 \%)$, the shipbuilding industry (16.3\%), the radioelectronics (32.6\%) and the ammunition and special chemicals industry (22.3\%). At the same time, according to the data of the Rosstat in the Russian industry in general in 2015 production of special purpose vehicles and equipment fell by $3.2 \%$, production and repair of ships rose by $6.3 \%$, aircraft production, including aerospace vehicles increased by $8.1 \%$, production of electronic components, hardware for radio, TV and communications decreased by $10.7 \%$ and production of device and instruments for measuring, checking, testing, navigation, control and other purposes rose by $6.2 \%$. Taking into account the fact that the above industries belong to the

1 The Government's Report on the 2015 Operating Results: Verbatim record. M., 19.04.2016. URL: http://government.ru/news/22717/ (date of application: 19.04.2016).

2 The 2015 main performance results of the Ministry of Industry and Trade of the Russian Federation. URL: http://government.ru/dep_news/22613/ (date of application: 20.04.2016).

3 The Military-Industrial Complex: the 2015 Important Outputs and Indices. URL: http:// government.ru/info/22714/ (date of application: 19.04.2016).

4 Rogozin: output volume of the Russian MIC will grow 4 times over by 2030// RIA Novosti. 2 October 2012.

5 The single day of acceptance of military products. URL: http://www.kremlin.ru/events/ president/news/51496 (date of application: 14.03.2016).

6 Production indices in the Russian Federation. Operating data for 2015. URL: http://www. gks.ru/free_doc/new_site/business/prom/ind_2015.xlsx (date of application: 29.01.2016). 
MIC's sectors, the difference observed in the statistical data of the Ministry of Industry and Trade and the Rosstat can be explained by a preliminary nature of the data.

In 2015 , the export of military products amounted to $\$ 14.5 \mathrm{bn}$ which is $6.5 \%$ less than the indices of the previous year. It is to be noted that due to general reduction of the Russian exports the share of military products in it rose within a year from $3 \%$ to $4.3 \%$. Over $\$ 26 \mathrm{bn}$ worth of new contracts was concluded, that is, the business portfolio increased from $\$ 47.7 \mathrm{bn}$ in 2014 to $\$ 56$ bn by the end of $2015 .{ }^{1}$

In summing up the results of implementation of the state defense order (SDO), the official data was made public on 11 March 2016. According to the above data, the SDO was fulfilled generally in the interests of the Ministry of Defense for $97 \%$ last year, which fact, according to Yu. Borisov, Deputy Defense Minister was "the highest index in the past years". ${ }^{2}$ However, the Deputy Defense Minister mentioned right away growth of Rb $242 \mathrm{bn}$ in overdue accounts receivables ( $\mathrm{Rb} 250 \mathrm{bn}$ according to other sources ${ }^{3}$ ) due to contract failures which factor makes that above achievement doubtful as the specified amount of the debt corresponds to the deficiency of not $3 \%$, but $13.4 \%-13.9 \%$ of fulfilment of the SDO amounting to Rb 1.8 trillion in 2015 according to the data available to the mass media. ${ }^{4}$

In accordance with the list of entities included in the composite register of MIC entities published by the Ministry of Industry and Trade in 2015, their total number increased from November 2014 by 14 entities to 1353 entities. ${ }^{5}$ Specifically, most newly-included entities (10 in 14) were subordinate to the Ministry of Defense and the Federal Biomedical Agency under which jurisdiction only the Research Institute for Biological Instrument-Making was listed in the past.

Territorial break-down of MIC entities by regions did not change much: as before nearly half of them (600 entities or $44.3 \%$ ) is situated in the Central Federal District where Moscow (315 or 23.3\%) and the Moscow Region ( 111 or $8.2 \%$ ) are the leaders. The $2^{\text {nd }}$ and the $3^{\text {rd }}$ places are shared by the Privolzhsky Federal District (236 or $17.4 \%$ ) and the North-Western Federal District (224 or $16.6 \%$ ) in which the Nizhny Novgorod Region (54 or $4.0 \%$ ) and St. Petersburg (168 or $12.4 \%$ ) dominate. In other federal districts, the Sverdlov Region (41 or $3.0 \%$ ) and the Novosibirsk Region (36 or $2.7 \%$ ) are the leaders. In the Crimea and the city of Sevastopol, the number of entities in the register rose from two entities to 7 entities (in

1 The meeting of the Commission on Military and Technical Cooperation between Russia and Foreign States URL: http://www.kremlin.ru/events/president/news/51593 (дата обращения: 30.03.2016); On the state of foreign trade in 2015 URL: http://www.gks.ru/bgd/free/b04_03/ IssWWW.exe/Stg/d06/35.htm (date of application: 26.02.2016).

2 The single day of acceptance of military products. URL: http://www.kremlin.ru/events/ president/news/51496 (date of application: 14.03.2016).

3 The Ministry of Defense short-received Rb 250bn worth of products from MIC enterprises // RIA Novosti. 20 April 2016.

4 O. Solovieva. State Orders for Defense Industry Enterprises will Shrink // The Nezavisimaya Gazeta. 20 April 2016. URL: http://www.ng.ru/economics/2016-04-20/4_mashino.html (data of application: 20.04.2016).

5 Order No.1828 of 3 July 2015 of the Ministry of Industry and Trade on Approval of the List of Entities Included in the Composite Register of Entities of the Military-Industrial Complex. URL: http://minpromtorg.gov.ru/common/upload/files/docs/Prikaz_N_1828.pdf (date of application: 06.07.2016). 
the Crimea there are totally 21 MIC entities, a portion of which is currently being reorganized) ${ }^{1}$

According to the data of the Ministry of Industry and Trade, in 2015 MIC entities carried out capital development at 368 projects of which 37 projects were put into operation: the aircraft industry (16), the shipbuilding industry (9), the radioelectronics (5) and the conventional armament industry and the ammunition and special chemicals industry (7). ${ }^{2}$

Generally, the defense industry of the Russian Federation includes over 4,000 entities engaging one way or another in production of military products and creating - according to T. Shevtsova, Deputy Defense Minister $14 \%-15 \%$ of $\mathrm{GDP}^{3}$, that is, the value exceeding the unit weight of all the manufacturing industries combined (13.4\% of GDP in 2013).

The Rosstat's annual data statistics on industrial GDP in a detailed format simplifies from this year the objective of determination of the direct contribution of the MIC to $\mathrm{GDP}^{4}$; for that purpose it is sufficient enough to exclude the gross added value of production of railway rolling stock and other transport vehicles (codes $35.2+35.4+35.5$ ) from the aggregate "production of ships, aircraft and aerospace vehicles, other transport vehicles and other materials and substances which are not included in other groups" (codes $35+23.3+24.61+29.6)$. The initial outputs and results of relevant calculations are shown in Table 1. It is evident that the received estimates of the unit weight of the MIC are explicitly overestimated due to the fact that output of medical goods was taken into account, however that makes them more reliable. The accuracy of such estimates can be upgraded by way of further itemization of types of economic activities.

Estimation of the indirect contribution of the MIC to GDP requires utilization of the "input-output" tables for taking into account the multiplier effect of inter-industry relations. As large dimension base tables developed by the Rosstat in 2015 for 2011 were not published so far, estimates were made on the basis of historic and foreign analogs, as well as small dimension tables which do not include explicitly the data on the MIC's products and sectors. Utilization of the 1959 interindustry balance of the national economy ${ }^{5}$ which was declassified after February 2008 permits to determine ratios of full costs (simple output multipliers) for products of the radio engineering industry (2.10), "other sectors of machinery" (1.79) and "other sectors of the industry" (1.67) omitted in publication of the $1^{\text {st }}$ quadrant of the balance in $1961 .^{6}$

1 The meeting of the Military-Industrial Commission. URL: http://www.kremlin.ru/events/ president/news/51306 (date of application: 15.02.2016).

2 The Military-Industrial Complex: The 2015 Important Outputs and Indices.

3 T. Shevtsova. Maintaining of the level of expenditures on defense is a prerequisite of stability today and economic growth in future // The Export of Arms. 2015. \# 1. pp. 61-62; A. Sharkovsky. The State Defense Order Gives Impetus to Industry // Independent Military Review. 22 April 2016.

4 National accounts. Industrial GDP. Annual data. The data in a detailed format. URL: http:// www.gks.ru/wps/wcm/connect/rosstat_main/rosstat/ru/statistics/accounts/\# (date of application: 06.04.2015).

5 The Performance Inter-Industry Balance of Output and Distribution of Products in the USSR National Economy in 1959. // RGAE. F.1562. OP. 41. D. 1430.

6 The USSR National Economy in 1960. Statistical Yearbook/Central Statistical Department at the USSR Council of Ministers : Gosstatizdat, 1961. pp. 104-143. 


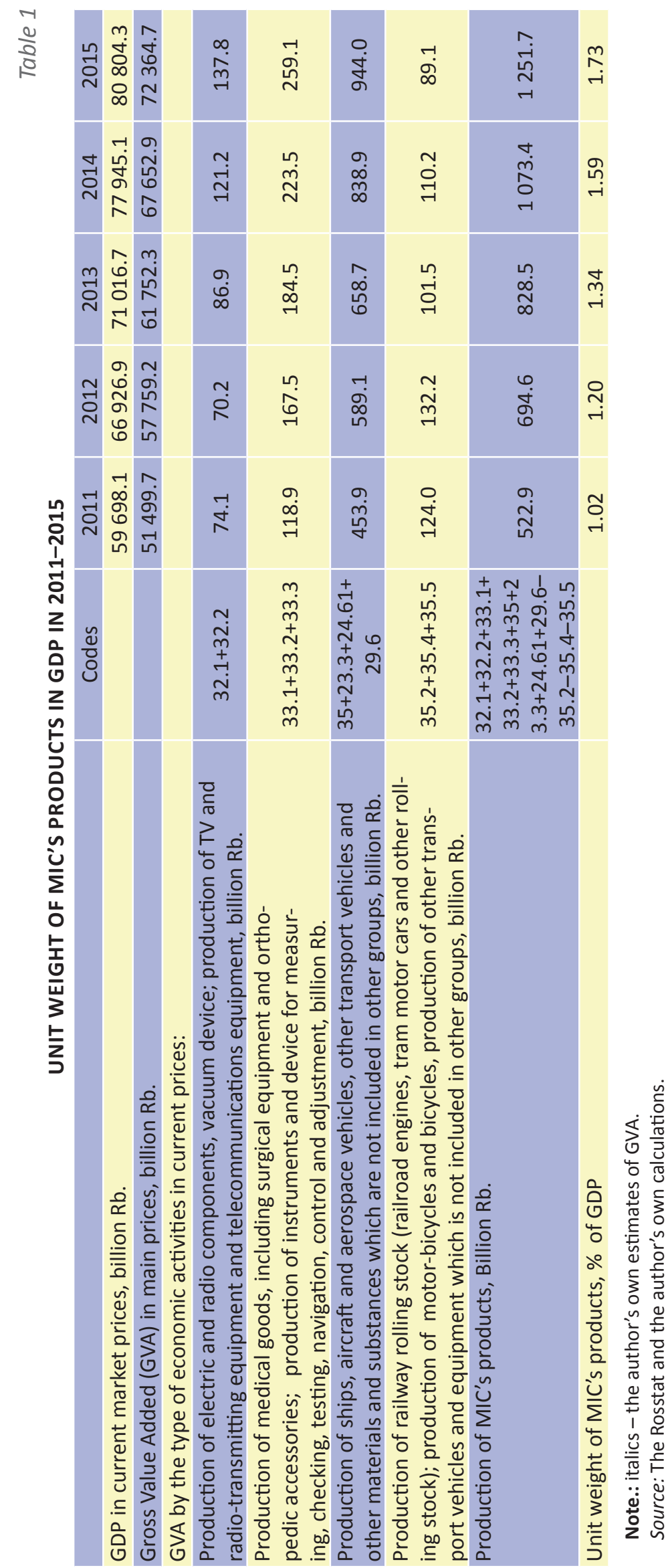


The 2011 "input-output" tables by 34 industries developed for Russia by the OECD statistical agency include the calculated simple sectorial output multiplier for "Transport Equipment" (2.03) and "Manufacturing, Nec; Recycling" (2.18) 1 .

However, the most detailed and open data on simple output multipliers are included in the 2007 "input-output" tables developed by the Economic Analysis Bureau of the US Department of Commerce by 389 sectors with ten of which attributed to the defense industry ${ }^{2}$. The values of multipliers for defense sectors are within the range of 1.87 to 2.38 with the average value of 2.11. The above value agrees with the data of the historic example and those received on the basis of the small dimension tables; it represents a reasonable estimation of the multiplier as regards the Russian MIC, too. As shown in Table 2, direct and indirect contribution of the MIC to GDP amounts on average to two-thirds of the value of the military burden on the national economy in respective years, while economic return from the MIC is overestimated, to say the least.

Table 2

THE MIC'S CONTRIBUTION TO GDP IN THE 2011-2015 PERIOD

\begin{tabular}{|l|c|c|c|c|c|}
\hline Military expenditures, \% of GDP & 2011 & 2012 & 2013 & 2014 & 2015 \\
\hline $\begin{array}{l}\text { MIC's direct and indirect } \\
\text { contribution, \% of GDP }\end{array}$ & 2.15 & 3.97 & 4.21 & 4.44 & 5.30 \\
\hline $\begin{array}{l}\text { MIC's contribution/mili- } \\
\text { tary expenditures, \% }\end{array}$ & 59.9 & 63.8 & 67.2 & 75.6 & 68.9 \\
\hline
\end{tabular}

Source: The Russian Economy in 2015. Trends and Outlooks (Issue No. 37). M.: The Publishing House of the Gaidar Institute, 2016. p. 465; the author's own calculations.

1 OECD.Stat. Input-Output Tables. URL: http://stats.oecd.org/Index.aspx?DataSetCode=IOTS (date of application: 20.04.2016).

2 Input-Output Accounts Data. URL: https://www.bea.gov/industry/io_annual.htm (date of application: 20.04.2016). 